\title{
Tokiko kultura-ondarea lantzeko pedagogia- eta didaktika-eredu baten beharra
}

\author{
Iñigo Ramirez de Okariz Telleria \\ «Berrikuntza eta esku-hartzea gizarte kulturanitz eta eleanitzetan» lerroa, \\ Humanitate eta Hezkuntza Zientzien Fakultatea, MU
}

\begin{abstract}
Pedagogia- eta didaktika-eredu berrien beharrean gaude; irakasleok horretaz jarduteko, ondarearen hezkuntzara garamatzan markoa ere diseinatu behar dugu. Hala, artikulu honek bi helburu ditu: ondarearen eta hezkuntzaren arteko balioetan sakontzea, eta diseinurako gakoak (genealogia, irakaslea, ikaslea, testuingurua eta edukia) identifikatu eta ezaugarritzea. Izan ere, hezkuntza-sistema modernoaren krisiarekin topo egin dugu azken aro honetan. Pedagogia-paradigma berrien beharrean gaude, non familiaren, eskolaren, komunitate osoaren inplikazioa beharrezkoa den, baina aurrekoari uko egin gabe, transmisioa bertan behera laga gabe. Esan nahi da gure ingurune soziokulturaleko ikasketa esanguratsuak erraztu eta sustatzeko ardura dugula hezitzaileok; hots, konpromiso bat daukagula ikaslearen nahiz irakaslearen identitatearen parte den natura- eta kultura-ondarearekin.
\end{abstract}

GAKO-HITZAK: Ondare-hezkuntza · Gizarte-zientzien arloa · Ondarearen didaktika · Tokiko kultura-ondarea - Eredu didaktikoa.

\section{Need of a pedagogical and didactic model to work the local cultural heritage}

We need new pedagogical and didactic models; in order for teachers to act on this, we must also design a framework that will lead us to heritage education. Therefore, this article has two aims. First, to examine the values that link heritage and education and then second, to identify and characterise keys for design (genealogy, teacher, student, context and content). In fact, we have found the modern educational system to be in crisis in recent times. We are in need of new pedagogical paradigms in which the involvement of family, school, and the entire community is essential, and in which this involvement is maintained without abandoning the transmission of knowledge. This means ensuring that educators will be responsible for facilitating and promoting meaningful studies on our socio-cultural environment; that is, studies that include the natural and cultural heritage that forms a part of the identity of both students and teachers.

KEY WORDS: Heritage education · Social sciences · Heritage didactics · Local cultural heritage $\cdot$ Didactic model. 


\section{Sarrera}

Historiak argi erakusten du zenbateraino konplexua den hezkuntzaren eta gizartearen arteko harremana. Horren harira, eta gizarte-aldaketaren izaeraren ikuspuntutik begiratuta, hiru aro historiko zabal bereizten ditu Fernández Enguitak (2001): lehen aroan, eskolarik gabeko gizartea. Hau da, eskola ez da erakunde gisa ikusten. Alegia, familian eta hurbileko komunitatean transmitituko dira haurren beharrezko ezagutzak. Bigarren aroan, modernitate-prozesuarekin bat eginik, dena aldatzen da, eta familiak eta hurbileko komunitateak garrantzia galtzen dute lehen mailako hezkuntza-eragile gisa. Hala ere, familia izango da oraindik sozializaziorako eragile nagusia, eta eskola, berriz, hezkuntza-eragile nagusi bihurtuko da. Baina, instituzio gisa eraiki zenean eskola, Estatuaren erantzukizun bihurtu zen, eta ez komunitate osoarena edo gizarte-aktore guztiena. Azken aroan, bukatzeko, hezkuntza-sistema modernoaren krisiarekin topo egiten dugu. Hots, gaur egungo testuinguru soziohistorikoarekin, hezkuntza-sistema modernoaren krisi estrukturalarekin, non, alde batetik, gaurko familia berriek sozializazioan duten gabezia hautematen den, eta, bestetik, eskolari eskatzen zaion sozializazio-funtzio horiek - haurren oinarrizko garapen afektibo eta moralaren zati handi bat ere bai tartean - betetzeko edo ordezkatzeko. Ondorioz, eskolak helburu larregi barneratu behar izan ditu, garai bateko irakatsi hartatik harago: prestatu, hezi, gizarteratu, motibatu, ordezkatu (gurasoak), kudeatu (aniztasuna), ondo pasarazi, jaten irakatsi, zaindu... Baina, aldi berean, eskolak irakatsi behar izan du krisi larrian bizi direla familiez gain komunitatea bera eta garai batean kolektibitateak osatu zituzten erakunde eta elkarteak ere (Azkarraga, 2010).

Horrek guztiak, bada, zera pentsatzera garamatza: pedagogia berriak behar dira, eta hartu beharreko neurrietako bat sareko hezkuntza (Nuñez, 2003) sendo bat osatzea izan beharko litzateke, non hezkuntza ardatz gisa harturik ezinbestekoa den eragile askoren parte-hartzea: familia, eskola, komunitatearen beraren inplikazioa eta transmisioa. Horren bitartez, gure haurrek jakintza berriak osatuko dituzte.

Alegia, dena delako hezkuntza-ereduan, beraren helburua transmisioa bermatzea dela jakinda, subjektua munduarekin harremanetan jarri beharko lukete lantzen diren hezkuntza-edukiek, arbasoek egindako kultura-ibilbide luzearekin, beste kulturaondare batzuekin, eta, nola ez, baita bere garaia interpretatzeko gakoekin ere.

Esan nahi da egungo hezkuntza-konpetentziei begira ez lukeela ekarri behar aurrekoari uko egitea, ezta transmisioa bertan behera lagatzea ere. Nuñez pedagogo sozialak dioskun bezala (2003), ez dago hezkuntzarik instrukzio-funtziorik gabe, hau da, jokoan jarri gabe kultura-ondareko zerbait, gizateriaren altxorren artetik zerbait banatu gabe, eta zerbait horrek hezkuntzan subjektu guzti-guztiak sinbolikoki kidetu gabe.

Irakasleok gara hezkuntza-prozesuko aktore garrantzitsuenak, eta gugan dago gure ingurune soziokulturalarekin loturiko ikasketa esanguratsuak errazteko eta sustatzeko ardura; horretarako, trebetasun espezifikoak jarri behar ditugu martxan. Baina gerta liteke -eta uste baino sarriago gertatzen da- kultura-ondarea ezartzeko corpus pedagogiko eta didaktikoa hain landua ez izatea eta ez bat 
etortzea ikaslearen garapen integratzailearekin; alegia, haren ingurunearekin eta, beraz, haren kultura eta identitatea babesteko beharrarekin hain lotuta ez egotea.

Egoera horri buelta emateko, baina, zera dioskute Valenzuelak eta Viloriak (2008: 259):

Para ello se hace necesario que el educador dé la importancia debida a la enseñanza del patrimonio cultural y natural como base de la identidad, pero a la vez que asuma la carga social que ello implica, lo cual requeriría de su parte un contacto mayor con su entorno, una búsqueda necesaria de sus raíces y un compromiso personal (...). Esto sólo se hará efectivo si el docente es preparado para tal fin.

Beraz, ezinbestekoa dugu, artikulu honen bitartez, ondarearen eta hezkun-tzaren arteko balioetan sakontzea eta tokiko kultura-ondarea lantzeko pedagogia- eta didaktika-eredu baten diseinurako gakoak identifikatu eta ezaugarritzea, eta bide batez, Valenzuela eta Viloriak (2008) arestian dioskuten bezala, zeregin horretarako irakaslea prestatzea.

\section{Ondarearen hezkuntza: prestigioa hartu nahian}

Irakasleok prestatu behar hori, baina, ez da gaurko kontua. Adibidez, aspalditik datorkigu ondarearen hezkuntza-balioaren esanahia nazioarteko erakundeetatik, eta horrek balio digu esateko nazioarteko kulturaren bitartekari-funtzioa duela ondareak hezkuntzan, baina baita, lurralde-eremu mota askori (nazio, erregio, herri) begira, interpretatzailearena ere. Baina noiztik datorkigu halako legitimazioa?

1956ko abenduaren 5ean, indusketa arkeologikoetan aplikatu beharreko arautegi bat onartu zuen UNESCOk, New Delhin. Lehendabizi, aipatu zen zer garrantzi zuen ondare arkeologikoak han, baita hezkuntzan ere. Arautegiaren 12. artikulura joan besterik ez dago horretaz ohartzeko (UNESCO, 2011a), eta bertan jakinarazten zaie agintari eskudunei iraganeko aztarnen inguruko errespetua sortu eta garatzeko ezinbestekoa dela hezkuntza-jarduna, horretarako historia bezalako diziplinaren irakaskuntza erabiliz, indusketetan ikasleen parte-hartzea sustatuz, interes arkeologikoa duten aztarnategietara bisitak antolatuz, egindako aurkikuntzen aurkezpen gardenak eginez edota egindako ikerketen monografiak eta gidak salneurri jasangarrian eta ulergarrian kaleratuz. Bide batez, UNESCOn parte hartzen duten estatuei ere jakinarazten zaie arestian aipatutako guneetan sartzeko eta bisitatzeko aukerak eman eta erraztu beharko dituztela.

Ondoren, Europar Batasunak ere bere gain hartu zituen aztarnategi arkeologikoetan aplikatu beharreko arau batzuk; zehazki esanda, bi hauek: V. ataleko 37. eta 38. artikuluak.

Hogeita hamazazpigarren artikuluari dagokionez, publikoaren, ikasleen eta irakasleen hezkuntza-mailako elkarrekintzaz diharduenean, eskola barruan zein kanpoan hezkuntza-ekintza bat sustatu behar dela diosku, haren bitartez tokiarekiko eta paisaiarekiko errespetua sorrarazteko eta sustatzeko, baina baita hura babesteko arauak ezagutarazteko ere. 
Arautegi bereko 38. artikuluaren arabera, berriz, arestian jakinarazitakoa betearazten saiatu behar dute irakasleek, eta, horretarako, prestakuntza berezia jaso behar dute erdi- eta goi-mailako ikastetxeetan (Avila eta Mattozzi, 2009).

Gure ibilbide kronologikoarekin jarraituz, kultura- eta natura-ondarearen babeserako hezkuntzaren nahitaezko zeregina azpimarratu zuen 1972an UNESCOk, seigarren atalean (UNESCO, 2011b), eta horretarako artearen historiaz, arkitekturaz, inguruneaz eta hirigintzaz sustatu nahi izan zituen ikastaroak, mintzaldiak unibertsitateetan, gradu ezberdinetako eskoletan, baita hezkuntza iraunkorrez arduratzen zirenetan ere.

1978an, berriz, UNESCOk zera aipatu zuen kultura-ondasun higigarriaren inguruan: kultura-ondasunak babesteko, eta horren bitartez nazio bakoitzak bere kultura-identitatea kontserbatzeko, autoritate nazional, erregional eta lokalak (bitartekariak, azken finean) bultzatzen saiatu behar du estatu bakoitzak, haien bitartez gazte eta nagusiek kultura-ondasun higigarriak ezagutu eta errespeta ditzaten, eta, horretarako, hezkuntza- eta informazio-baliabideak erabili behar dira (UNESCO, 2011c).

Beraz, hezkuntzaren bitartekaritza ezinbestekoa da dugun kultura- eta naturaondarea ezagutzeko eta horretaz jabetzeko, bata zein bestea ezinbestekoak baitira ondarea ulertzeko eta balioesteko.

Baina hori hezkuntza zentzu zabalean ulertuta egin behar da, eta ez eskolara (hezkuntza formala) soilik zokoratuta, baizik eta beste hezkuntza-eremuak (ezformalak eta informalak, alegia) ere aintzat hartuz, horrekin guztiarekin benetako hezkuntza-komunitate bat lortu eta geurea den kultura-ondarearen transmisioa -etorkizuna, azken finean-ziurtatzeko.

Ondarearen transmisioaren etorkizuna, gure iritziz, hezkuntzatik pasatzen da batik bat. Bera da eragile garrantzitsuenetakoa, nahiz eta bakarra ere ez dela jakin. Horrekin, zera esan nahi dugu: gai izango bagina eskolako lehen mailetako haurrekin hasita euren ondarearekiko sentsibilitate handia lortzeko herri-, mankomunitate-, herrialde- edo, zergatik ez, nazio-mailako hezkuntza-proiektu bat diseinatzeko eta garatzeko, etorkizunera begira gure ikasleen lanbide-hautuak zein diren gorabehera, askoz hobeto prestatuta egongo lirateke ondarea ulertzeko, balioesteko eta besteoi transmititzeko.

Beraz, ondarearen hezkuntza inbertsio bat da etorkizunera begira, baina, gure ustez, planifikazio bat behar du, elkarrekintzan —alegia, herriko edo/eta bailarako eragile komunitarioen arteko adostasunean- oinarritutakoa. Esan nahi da denon artean eredu didaktiko adostu eta egokia diseinatu behar dela, nahiz eta zeregin horretan hezkuntza formalak izan funtziorik garrantzitsuena amets eder hau egia bihur dadin. Izan ere, didaktikak, irakaskuntza-ikasketa prozesuak izateaz gain, pertsonak inplikatzen ditu; gizabanakoen nahiz taldeen ekintzen bidez garatzen den harreman bat da, alegia. Eta ondareak, ostera, ondasunen eta pertsonen arteko enpatia batean eragiten du, eta hori norberarena da, propietatea eta identitatea elkarrekintzan jartzen dituelako (Fontal, 2008). 
Errealitate bat da, gaur, ondare historikoaren kontserbazioarekin eta zaharberritzearekin loturiko interesa gero eta handiagoa dela urrutiko nahiz gertuko gizartean, eta horren lekukoetako bat hedabideak izan daitezke; izan ere, gero eta arreta handiagoa ematen zaie zaharberritu eta publikora zabaldu diren interpretaziozentro, jauregi, museo eta abarrei, herritar guztien gozamenerako. Turismo kulturalaren eraginez ere, ez dago bidaiarik non ez dugun ondare-elementuren bat ikusi barik lagatzen, grafikoki adierazten ez dugunik. Beraz, ondarearen kontzeptua gero eta gertuagokoa izateaz gain, badirudi bide batez gertuko errealitateko gizarte soziokulturalak ulertzeko aukerak ere zabaltzen zaizkigula.

Ondareak hezkuntzan izandako bilakaera ondarearen kontzeptualizazioak mendeetan zehar izan dituen prozesu edo gorabeherekin bat ulertu behar dugu. Hala, XVIII. mendean, artelanen bilketa zen xede nagusia, eta ordukoak dira lehendabiziko museoak. XIX. mendean, berriz, artelanen sistematizazioan datza aldaketa, eta museografian eta ondarean elkarrekintza-irizpideetan aurreratu zen. XX. mendean, ostera, ulermenean dago gakoa -ondare kontzeptuaren aberastasunean, alegia-, eta elementu materialetatik ondare immaterialetara pasatu zen. XXI. mendean, bukatzeko, aprobetxamendua da hitz nagusia, eta lurraldearen garapenarekin eta lurraldearekin berarekin lotzen da (Fernández, 2005).

Hezkuntzan, berriz, ezarpena motelagoa izan da, nahiz eta curriculumak ondareaipamenak adierazi. Hala ere, aipamenak aipamen, historikoa eta artistikoa denari atxikitzen zaio batik bat ondare kontzeptua, eta gizarte-zientziekin eta gizarte esperimentalekin loturiko beste adierazpen batzuekin dauden hutsuneak, ostera, nabarmenagoak dira (Ávila, 2005).

Harago doaz Estepa (2001: 93) eta Cuenca (2003: 37) adituak; izan ere, zera dioskute ondarearen funtzioa zer den eta ez den adieraztean:

La didáctica del patrimonio no tiene como finalidad directa el conocimiento de los elementos patrimoniales, ni el patrimonio para ser un nuevo contenido a añadir a la asignatura de conocimiento del medio en educación primaria, o de ciencias sociales, geografía e historia de la ESO, ni un motivo para llevar a cabo salidas extraescolares que puedan hacer más actrativas estas asignaturas para los alumnos, sino que debe de integrarse en el currículo y en particular en la enseñanza de las ciencias sociales, para permitir una mejor comprensión de la realidad social.

Arestian azpimarratutakoarekin hauteman daiteke baliabide sozial gisa ulertuta berpizte eta bideraketa bat izan duela ondareak azken urteetan, eta horren eragileak bi izan dira: lehena, ondareak globalizazioaren eta homogeneizazioaren aurrean desberdintasunaren elementu gisa eragitea komunitate batean. Bigarrena, ondarea bera kultura bateko espezifikotasunaren jabe bihurtzea eta globalizazioaren merkatuan lehiatzea.

Hori aintzat hartuta, hezkuntza ezin da eskuak gurutzatuta geratu testuinguru berri honen aurrean, eta ondareak beste dimentsio (helburu) batzuk jorratu behar ditu; sinbolikoak eta ukiezinak, esate baterako (Fernández, 2005). 
Are gehiago, ondarearen erabilera ezin dugu oinarritu, gaur egun bezala, aktibitate isolatuetan: benetako zeharkako zereginetan ahalegindu beharko genuke, eta tratamendu pedagogiko eta didaktikoa ideala izan daiteke, gure ustez, Oinarrizko Hezkuntza osoari begira aplikatzeko.

\section{Ondare-hezkuntza}

Hezkuntzak bat egiten du esandako ondare kontzeptuaren bilakaera horrekin, baina egokitzapena uste baino motelagoa izaten ari da, eta hutsune ugari ditu, Pagés, Estepa eta Travéren iritziz (2000). Hala ere, XIX. mendetik hona izandako aldaketak nabarmenak izan dira, batik bat pertsonak ondarearekiko duen funtzioa aldatu delako, pertsona baliabide kultural horien aurrean erabiltzaile eta gestore bihurtu delako aldi berean. Beraz, Fernándezek dioskunez (2005), gaurko ondarearen legitimaziorako baliagarriak izan litezkeen jarrerak eta gaitasunak eskaintzen ditu hezkuntzak. Alegia, ondarearen ezagutza eta, aldi berean, errespetu eta sentsibilizazio hobeagoak lortzea bada xedea, garrantzitsuagoa da herritarrak kulturarekin batera hazi eta heztea.

Eta hori nola egin? Olaia Fontalek (2003) esandakoarekin bat egingo dugu. Berak diosku ondare-hezkuntzaz bere osotasunean, baina baita bere aldagaiez ere okupatuko litzatekeen marko teoriko espezifiko bat behar dugula horretarako.

\subsection{Ondare-hezkuntza: kontzeptua eta funtzioak}

Colom (1998) izan da lehendabizikoetako aditua ondare-hezkuntza terminoa erabiltzen. Ondare hitza darabilenean, baina, bi hezkuntza mota bereizten ditu: alde batetik, anbientala, eta, bestetik, kulturala. Anbientala zera da: inguratzen gaituen ingurumenaren oinordetza naturala eta balio ekologikoak dituena; alegia, bertan bizitza sortu eta garatzen duena. Kulturala, ostera, iraganeko eta oraingo oinordetza kulturalen aztarna eta laginak dira; gure oroimen kolektiboan galdu eta berritzen dena, alegia.

Beraz, bitxitasun bat badago guretzat aparta dena: Colomek (1998) iraganaren eta orainaren artean egiten duen lotura. Fontalentzat (2003), horrek zera dakar: iraganeko ekoizpena (hurbila eta urruna) gaurko proposamenekin (baina ez era desberdindu batean) era hezigarrian landuz.

Esanak esan, Colomek (1998) honela definitzen du ondare-hezkuntza (1998: 127): «Todos aquellos aspectos que son patrimonio del género humano y que, por tanto, nos fueron legados por las generaciones pasadas - como verdadera herenciay que ahora, mediante la educación, queremos también legar como patrimonio a la humanidad que nos ha de suceder». Definizio interesgarri horretan, entresaka interesgarri bat egin genezake; izan ere, hezkuntzaren zeregina identifikatzen du, hau da, belaunaldien arteko transferentzia-prozesutzat hartzen du ondarea.

Colomek, bada, errealitate kulturala eta naturala hartzen ditu aintzat ondarehezkuntza definitzerakoan, eta guri ere aproposa iruditzen zaigu. UNESCOK berak 
ere, Helsinkin, ondarearen definizio tradizionala aldatzeko erabakia hartu zuen 1998an, eta, haren arabera, elementu natural eta kulturalak, ukigarri eta ukiezinak, oinordekotzan hartu edo duela gutxi sortuak lirateke (Ballart eta Tresserras, 2001). Definizioan, bada, hauteman daiteke sintonia dagoela UNESCOren eta Colomen artean'.

Hala ere, nahiz eta ondare-hezkuntzak ondarearen errealitate integrala ulertzeko joera izan (naturala eta kulturala), egoera beste bat da hezkuntzan, eta arrazoiak hauek izan daitezke (Fontal, 2003): 1) irakasleriaren formazioari begira, ez da integrala; 2) bataren zein bestearen metodologiak ere desberdinak dira; 3) Ingurunearen Ezagutza jakintza-arloaren barnean ez bada, ez da erraza biak egituratzea, eta 4) hezkuntza ez-formalak eskaintzen dituen museoak, interpretaziozentroak eta halako baliabideak espezifikoak dira, eta ez integralak. Beraz, hasteko, ondare-hezkuntzan ${ }^{2}$ bi elementu bereizten dira: kultura-ondarearen hezkuntza eta natura-ondarearen hezkuntza.

Juanola, Calbó eta Vallések (2006) eta Fontalek (2008) beste argibide interesgarri bat eskaintzen digute ondarearen eta hezkuntzaren arteko kontzeptuaren ildoan, eta hiru ezagutza mota eta funtzio bereizten dituzte kontzeptu horretan: 1) ondarearen inguruko ezagutza (gaitasun hauekin lotuta: behatu, hauteman, adierazi...); 2) ondarearen bitartez lortutako ezagutza (ezagutza hautemangarria, adierazgarria, jarrerazkoa...), eta 3) ezagutza ondarearentzat (errespetuzko jarrerak garatu, kontserbaziozkoak...). Gainera, proposatzen dute heziketa orokorraren zati bat izan behar duela ondarearen hezkuntzak; besteak beste, pertsonen eta norberaren kultura garatzen laguntzen duelako.

Hiru ezagutza mota horiek elkartuz, gainera, aipatutako adituek dioskute ondarearen hezkuntzak bitartekari nahiz eragile ona izan behar duela edozein hezkuntza-etapatan, testuinguru askotarikoetan eta gizabanakoen nahiz kolektibateen eremuetan; izan ere, horrek zera indartzea dakar: «La educación sensorial, perceptiva, corporal, especial, emocional, expresiva y comunicativa, activa, comprensiva, estética, cognitiva y crítica, ambiental, multicultural, ética e inclusiva» (Juanola, Calbó eta Vallés, 2006: 28).

Esandakoak esanda, hezkuntzan ondareak duen funtzioa eta potentzialtasuna zabala da. Demagun, adibidez, historia hartu eta erabili nahi dugula diziplina zientifiko gisa. Horretarako, paregabeko lehen mailako iturri gisa, erabilgarria da ondarea, iturri esanguratsua izan baitaiteke, eta beste potentzialtasun bat erakuts baitezake aldi berean: ezagutza historikoa.

Baina ondareak baditu beste potentzialtasun batzuk (Hernández, 2003):

1. Begirada gertuago jarriz, arestian azpimarratutako ondarearen aspektu bikoitza (naturala eta kulturala) alde batera lagatzen du, adibidez, 7/1990eko Euskal Kultur Ondarearen Legeak, non alderdi kulturala den monopoliorako eta araubiderako gai.

2. Frantzian, éducation au patrimoine; Ingalaterran, heritage education; Argentinan, Venezuelan, Txilen eta Perun, esate baterako, educación patrimonial. Beraz, sintonia bat badago, adierazle komuna erabiltzen delako. 
1. Integratzailea da. Izan ere, badaki geografiako, arteko, historiako eta beste diziplina batzuetako kontzeptuak erabiltzen, eta, bide batez, diziplinartekotasunaren espazioa zabaltzen eta ulertzen laguntzen digu.

2. Tokiko ondare-elementuak ezagutzeaz gain, inguru hurbiletik harago doazen ondareak ulertzeko ere ona da.

3. Askotariko gaitasunak erabiltzeko aproposa ere bada, batez ere balioei loturik. Alegia, hautematearekin eta gozamenarekin lotuta dago, baita hezkuntza ez-formalari begira museoetara eta beste ondare-espazio batzuetara egiten ditugun bisitaldiekin ere, eta balioekin lotzen da (ondarearen zainketa, garbiketa, babesa, etab.). Beraz, balio-transmisiorako ere oso interesgarria da ondarea.

Arestian Hernándezek (2003) esandakoarekin ere bat etorri arren, Lehen Hezkuntzako Ingurunearen Ezagutzaren curriculumari egiten dioten azterketa aintzat hartuta, Llobet eta Valsek (2003) baliabide gisa ematen diote garrantzia ondareari; izan ere, haren erabilerak zera ahalbidetzen du: 1) beste zibilizazio, kultura eta gizarte batzuen ezaugarriak ezagutzea eta horren bidez iraganaren eta orainaren aurrean kokatzea; horretarako, ondarearen elementu gisa ikusten diren dokumentuak behatu, aztertu eta manipulatzen dira; 2) ikerketara eta lan zientifikoetara hurbiltzea, historiaren teknika eta erreminta propioak erabiliz; alegia, behaketa zuzena, informazio-bilketa eta trataera, eta ondorioztatzea; 3) enpatia, kuriositatea, jakiteko grina, erantzunak topatzeko gosea eta halako ezagutzak alderatzeko aukera izatea; 4) konpetentzia ugari lantzea, trebetasun desberdinak garatuz; 5) diziplinarteko nahiz beste jakintza-arlo batzuetako lanak (geografia, historia, artea, soziologia, antropologia, hizkuntza, matematika, arte-adierazpena...) sustatzea; edota 6) askotariko espazio-dimentsio eskalak lantzea.

\subsection{Ondarea hezkuntzan: bilakaera didaktikoa}

Colomek (1998:128-129), hezkuntza ez-formalari buruz diharduenean eta ondare kontzeptua definitzerakoan, ondareak duen izaera polisemikoa azpimarratzen digu, zera esanez: inguru batean dauden alderdi fisiko eta naturalak nahiz soziokulturalak ere adierazten ditu ondareak. Adierazpen horiek, baina, ez arbasoengandik edo tradiziotik jasotakoak soilik, baizik eta norberak bizitzan zehar eskuratutakoak ere izan daitezke. Hori aintzat hartuta, bada, honela definitzen du hezkuntza-ondarea: «Toda actividad educativa y formadora orientada a la conservación, mantenimiento y mejora de los patrimonios socioculturales y fisico-naturales con que cuenta una comunidad determinada». Beraz, hauteman daitekeen bezala, ondare-hezkuntza bi alderdiren jabe ere bada: natura-ingurunea eta ingurune soziokulturala.

Eduki didaktiko gisa ere, azken hamarkadetan ondareak aldaketak izan ditu bilakaeran. Atzera joz, eta XIX. mendetik hasi eta 1945era sortu ziren estatunazioen sorrerarekin eta osaketarekin bat eginez gero, ondarea helburu politiko batzuk lortzeko baliabide ona dela ulertzea ekarri du. Azken finean, identitateikurrak eta adierazpen kolektiboa ulertzeko erabili da ondarea, baina, aldi berean, baita besteengandik desberdintzeko eta kulturen arteko balio-eskalak sortzeko ere (Ramirez de Okariz, 2014). Horrek guztiak eragina izan zuen hainbat eremutan, UZTARO 107, 77-99

Bilbo, 2018ko urria-abendua 
baita hezkuntzan ere, haren balio nazionalak suspertzeraino; eta, are gehiago, horren ondorioz, industrializatu gabeko kulturetan ikuspegi negatiboa sortzeko bai eta kultura handia zer den ulertzeko profila ere suspertu zen. Horrek ondarea historia eta kultura nazionalarekin identifikatzea dakar, eta herrialde eta lurraldeen artean desberdintasunak sortzea.

XX. mendearen lehen erdiko gerrek, ostera, perspektiba-aldaketa bat ekarri zuten. Alegia, desberdina dena ulertzeko bitartekari bihurtu zen ondarea; hiriak eta lurraldeak ulertzeko laguntza eskaintzen zuen. Aurreko garaietan ez bezala, kultura desberdina ez zen kultura gutxitu edo nagusi gisa adierazten, eta beste herriei eta haien ondareari zor zaien errespetuarekin hasten zen. Esan nahi dugu herrien kulturen artean komuna dena azpimarratzen zela, eta desberdintzen gaituen horretatik elkar trukaketarako harreman solidarioak sor daitezkeela.

Beraz, ariketa sinple horretatik hauteman daiteke hasiera batean nagusitasuna eta zibilizazioaren zabalkundea adierazten zela eta ondarea hor barneratzen zela; ondoren, berriz, berdintasuna eta errespetua izan ziren transmititu beharreko ondare horren balio berriak. Esan beharrik ez dago UNESCO erakundea izan zela ondarearen gainbalioaren suspertze horren eragile, eta horren pizgarri izan zen 1972tik aurrera Gizateriaren Ondarea, Kultura eta Natura Babesteko Hitzarmena. Kultura-, politikaeta hezkuntza-ondarea ere zehaztu eta arautu ziren, nahiz eta azken hamarkadetan beste erakunde batzuk ere aintzat hartu behar diren zeregin horretan, Europako Kontseilua nagusiki. Halakoak ondare-hezkuntza politiken iturburu bihurtu zaizkigu, nahiz eta gero aplikazio-mailan herrialdeen arteko desberdintasunak agerikoak izan .

1980tik gaur arte, bilakaera bukatzeko, ondarea eragile indartsu bihurtu da lurraldearen garapenean. Ondareak norberaren baliabideak ezagutzeko baldintzak eskaintzen dizkio hezkuntzari, baina, aldi berean, baita sortu berriak edo kanpotik datozenak aprobetxatzeko moduak ere. Estrategia aldetik, tokikoaren eta globalaren arteko harremanak suspertzen ditu, eta ondarearen kudeaketa eta aprobetxamendurako arautegi sozioekonomikoak (eta lurraldekoak) adierazten ditu, batez ere teknikari eta politikarien mesederako.

Azken urteetan, berriz, nabaria da ondarearen interes soziala, eta kulturaturismoan nahiz aisialdiarekin loturiko jardueretan oinarrizko elementu bihurtu da herrialde garatuenetako industria osteko gizarteetan, eta halaxe funtzio bikoitza betetzen du: heziketa ez-formalean informazioa zabalduz eta kultura-identitate desberdinen aitorpen dibulgazioa eginez (Estepa, Wamba eta Jiménez, 2005).

Ondareak funtsezko funtzioa izan dezan hezkuntza-curriculumetan, hezkuntzaren eta ondarearen elkarrekintza bikaina ikusten du Fernándezek (2005). Zertan datza baieztapen hori? 1) ondarea ez da diziplina baten zeregina, baizik eta diziplina askotara zabaldu beharrekoa; 2) diziplina horiek, baina, gizarte-zientzien munduarekin lotzen dira batez ere, ondarea arlo horrekin loturiko helburu, eduki eta metodoen oinarri izanik; 3) lurraldearekiko beste ikuspegi bat izatera bultzatzen du ondareak; alegia, kanpotik etorritakoen edo gu baino gutxiago direnen ekarpenak ere balioesten ditu; 4) globalizazioak eragindako kultura homogeneoen aurrean identitate-balio propioak, singularrak berresteko balio du ondareak, hezkuntza- 
curriculumean ondo txertatuz gero; 5) ondasun kulturalen egiazkotasuna eta osotasuna mantentze aldera, eredu jasangarriagoak eta orekatuagoak eskatzera bultzatzen gaitu.

Beraz, esandako guztia aintzat hartuta, esan genezake ondareak zeharkako ezagutzak eskaintzen dizkigula; trebetasun, balio eta jarrerak, alegia.

\subsection{Ondare-hezkuntza: orientazioak}

Ondare-hezkuntzaren hezkuntza-orientazioak ugariak izan daitezke, eta hiru prozesutan zentratuta hauteman daitezke: interpretazioan, zabalkundean eta kudeaketan.

1) Interpretazioa. Ballarts eta Tresserrasek dioskuten bezala (2001), ondarearen interpretazioa oso zeregin konplexua da, galdera askori erantzun behar baitio (zer interpretatzen dugun; nork interpretatzen duen; zein diren interpretatzeko helburuak, eta abar), eta, horren ondorioz, subjektibotasunaren arriskua dago.

Baina, komunikatzeko prozesu bat ere badenez, hezkuntza-jarduera ere izan daiteke, kontuan hartzen badugu jarduera horretan askotariko eragile eta aldagaiak daudela: ikasten duen subjektu bat, irakasten duen beste bat, eduki batzuk, metodologia bat edo batzuk, eta erreferente teoriko eta metodologiko bat. Hala eginez gero, eta Fontalen ideia da (2003), hezkuntza-ondarea egiten ari garela esan genezake.

Interpretazio bera hezkuntza informalean ere sostengatzen dela diosku Romerok (1998); izan ere, bisitaldi bat egiten dugunean ondare-leku batera, martxan jartzen dira irakaskuntza-ikasketa prozesu boluntarioak, arakatze-mailakoak, ikastekoak, ez derrigorrezkoak baina bai ulergarriak direnak.

2) Zabalkundea. Jaso dugun ondare baten edukia ezagutaraztea izango litzateke. Zabalkundea, baina, dibulgazio gisa ere uler daiteke; Ravé, Respaldiza eta Fernándezen hitzetan (1997: 165): «El conjunto de actividades encaminadas en dar a conocer el Patrimonio y poner los medios y los instrumentos para que sea apreciado, respetado y disfrutado por el mayor número de personas». Baina zabalkundea ez da soilik informazioa komunikatzea, baizik eta baita estimulatzea, hausnarketa eragitea, probokatzea eta konprometitzea ere (Ballarts eta Tresserras, 2001). Eta, gure iritziz, hori lortu beharko litzateke hezkuntza-ikusmiratik gure eskola-jardueretan.

3) Kudeaketa. Esan gabe doa ondare-baliabideek paregabeko balio ekonomikoa dutela. Ikusi besterik ez dago artelan-merkatuetako enkanteen salerosketetan erabiltzen diren dirutzak zenbatekoak diren edota azken urteetan ere han eta hemen barreiaturik turismo kulturalak nolako indarra hartu duen. Baina, komunitate batentzat, harago doa ondare-balioa; izan ere, identitate-balioa ere badu, eta orduan konturatzen gara hezkuntza-produktu ere bihur genezakeela ondare-baliabide hori. Alegia, ez soilik balio soziopolitikoa, ekonomikoa edo komunikazio-mailakoa, helburua soziala ere izan dezakeelako ondare horrek, eta bide batez komunitate baten kohesioa eta garapen soziala lortzeko baliagarri bihurtu. Baina hori guztia kudeatu beharra dago; ez da berez garatzen (Ramirez de Okariz, 2017). 
Ondarearen kudeaketaz hitz egiten denean, tokiko administrazioa datorkigu burura, eta Mejíasen (2008) ikuspegia ez da batere baikorra; izan ere, tokiko administrazio gehienei dagokienez, historia-ondareak bizi duen egoera ez da batere baikorra, eta, batzuetan, eskasa ere bai, batez ere giza baliabideetan zein teknikoetan, baina baita planifikazio- eta kudeaketa-erremintetan ere.

\subsection{Ondare-hezkuntza: identitatea}

Azkenengo urteetan, ondarearen presentzia areagotuz joan da curriculumean, eta Lehen eta Bigarren Hezkuntzako curriculumetan ondare-edukiak landu beharraz ohartu dira (Ramirez de Okariz, 2015a). Ondarea, hala, bitartekari ona da iraganarekin, gure oinordetza historikoarekin eta balio estetiko, artistiko, teknologiko, historiko eta abarrekin zubi-lanak egiteko. Izan ere, ondareak iragan historikoa bistarazten digu, eta ia-ia bakarra da historia zuzen behatzeko; horregatik, baliagarria izan daiteke iraganaren hurbilketa zientifikorako ere (Hernández, 2003).

Ondarea eduki, helburu, xede edo bitartekari izan daiteke irakaskuntza-ikasketa prozesu batean, baita dena aldi berean ere. Izan ere, eduki izan daiteke eduki espezifiko batekin lotzen badugu - demagun, ondasun historiko eta artistiko batekin-; helburu, nahi bat lortu nahi dugulako ondare horrekin —ezagutu, ulertu, sentsibilizatu, transmititu-; xede, berriz, identitate-ikuspuntutik ari bagara, gure ondarea nahiz inorena ulertarazten, sentitzen, bereganatzen saiatzen garelako; bitartekari, baliabide didaktiko edo estrategia gisa planteatzen dugulako — demagun, ibilbide bat-. Hori guztia ondarean heztea izan daiteke.

Ondare-hezkuntzarenxedearierreparatu nahidiogu.Beraz, xedeapatrimonizatzea bada, horrek adieraziko luke bai taldean baita ikasten ari den subjektuarengan ere eragiten duela ondarearen identitate potentzial efektiboak. Hori esanda, galdera da ea ba ote dagoen identitate-erreferentearen eraikuntzan oinarritutako hezkuntza bat garatzerik ikasten ari den subjektu edota talde batean oinarrituta. Fontalek garbi du ez soilik posible, baizik eta beharrezkoa ere badela (2008), horrek adieraziko bailuke garrantzia ematen diogula ondarearen dimentsio sozialari. Beraz, gizabanako eta taldeen potentzialtasunak zentzu handiagoa hartzen du euren identitatearen eraikuntza-prozesuan; izan ere, norbanakoaren edo norbanakoaren kolektibitatean egiten den inplikazioa zuzenagoa da, baina, bide batez, baita psikologikoa ere.

Zeregin horretan, Freireren esanak (1973) baliagarriak bezain aplikagarriak, balekoak, ikusten ditugu gaur ere, nahiz eta haren eta gure espazioa eta denbora bat ez etorri. Freirek adierazten digu zein diren hezkuntzaren printzipioak, eta euretatik bereizketa bat egiten dugu ondarearen didaktikarako aplikagarriak izan daitekeelako. Kontzientziazioa eta sentsibilizazioa dira printzipio horiek. Bata zein bestea oinarrizkoak ikusten ditugu ondare-hezkuntzarako. Baina, bi ideia horietatik, kontzientzia hartzeari erreparatuko diogu, kultura-identitateen eraikuntzan eta hausnarketan oinarriturik. Ez baita gauza bera ondarea oro har harturik edo nire ondarea. Alegia, hezkuntza-ikusmira batetik, komeni da ondarea lantzea ikasten ari diren subjektuetatik abiatuta, euren identitateak osatzen joatea, euren ondarea era sinbolikoan bereganatu dezaten. Kontzientzia-hartze horrekin, eraldaketa-praktika 
bat martxan jartzea lortzen dugu; alegia, ondare-hezkuntzara atxikiz, subjektuaren kontzientzia kritikoa erraztu eta garatzea (Freire, 1973; Ramirez de Okariz, 2015b).

\subsection{Ondare-hezkuntza: komunikazioa}

Esandakoetatik hauteman daiteke hezkuntzak eta ondareak uztarriak antolatu dituztela elkarlanean aritzeko. Baina bata eta bestea ez litzateke ezer izango komunikazioak bitartekari-lana egingo ez balu. Esan nahi da irakaskuntzaikasketa prozesuaren barruan planteatzen diren prozesu komunikatiboei esker bermatzen direla hezkuntza eta transmisioa. Eta ondareak — belaunaldi batetik besterako transmisioaren emaitza gisa ulerturik- errazten eta bideratzen ditu ezagutza-prozesuak, zabalkundea bera, giza ikasketa, balio kulturalak, identitateen eraikuntza... Aldagai horiek guztiak bide onetik joan eta etekinak izateko, baina, belaunaldien, gizataldeen, politikarien, ideologoen eta abarren arteko komunikazioa bermatu behar da. Ideia berekoa dugu Fontal ere (2008: 106): «La educación patrimonial es, desde esta perspectiva una actividad que pretende establecer una comunicación eficaz entre el patrimonio cultural y su potencial público, propietario, legetario o depositario de la identidad».

Hezkuntza ez-formalari lotutako diskurtsoan oinarritzen bada ere, publikoari (guretzat, eskolako umeei) transmititu nahi diogun diskurtso bat eraikitzeko orduan, bermatu behar dugu entzulea gai dela esandakoa ulertzeko, bai alderdi intelektualetik, bai emozionaletik. Gertatzen da euskarri mota asko erabiliz teknizismo asko eta esanguratsua ez den informazioa eskaintzen dela sarri transmisio horretan. Beraz, lehenik eta behin, hauteman behar dugu nori dagoen zuzenduta mezua, zer aurrezagutza duen gaiarekiko eta nola bihurtu erakargarri eta ulergarri adierazi eta komunikatu nahi dieguna; horretarako, ondarearen didaktikak eskaintzen dizkigun erremintak erabiliko ditugu.

Esan gabe doa badagoela laguntza gehiago behar duen publikoa; guretzat, eskolako umeak. Beraz, komunikatu nahi diegun hezkuntza-mailako jarduera horrek bestelako helburuak izan beharko ditu. Publikoaren ezaugarriek, bada, baldintzatzen dute kultura-ondarearen zabalkundea, eta Fontalek (2008) hiru aukera ikusten ditu aintzat hartu beharrekoak publiko horri begiratuta: hezigarria, dibulgatzailea edo prebentiboa, eta ludikoa ere izatea, nahiz eta azken hori eranskin gisa ulertu behar den edozein diskurtsoren barruan; izan ere, azkenean, bisitan datorrenaren arreta bereganatu eta maila batean mantendu nahi izaten da, horren bitartez hezkuntzahelburu bat lortu ahal izateko (Mateos, 2008).

\subsection{Ondare-hezkuntza: diziplina askoren espazioa}

Ondarearen kudeaketaren barruan, zein da hezkuntzaren zeregina? Ondarehezkuntza esan izan zaionarekin lotuta, aditu asko (Colom, 1998; Pastor, 2004; Fontal, 2003) ari da eskatzen diziplina askoren hausnarketa-espazioa izan dadila, horren bitartez teoria eta metodologia zehatzak lortzeko. 
Fontalek dioskun bezala (2003:166):

Asumimos la Educación Patrimonial como un proceso pedagógico centrado en las percepciones, conocimientos y valores que subyacen en una sociedad. De esta manera, el bien patrimonial se convierte en un recurso para el aprendizaje, capaz de conectar al ciudadano con su diversidad cultural y su entorno social. Para ello, es necesario trabajar con los valores culturales locales más próximos a las personas, para luego proyectar los valores universales. El diseño, planificación y ejecución de acciones educativas tendrían como objeto de estudio el diseño de estrategias y recursos educativos centrados en las personas y no en el bien cultural.

Ondare-hezkuntzaren garapena ezagutza-arlo gisa garatu nahi izanez gero, inguruan dagoeneko bidea egina duten espezialitatetan oinarritu gaitezke. Lehenik eta behin, hezkuntzak berak erreferentziazko egitura metodologiko bat eskaintzen digu, baina baita estrategia zehatzagoak ere, ondarearekin hertsiago lotutakoak. Bigarrenik, Ingurumen Hezkuntzak ibilbide luzea egin du ondare naturalaren inguruan. Animazio soziokulturalaren arloak ere erremintak eskain diezazkiguke, arlo horretan asmatu baitira, herritarren parte-hartzea bultzatu nahian, ondarearekin loturiko arazoak konpontzeko hezkuntza-estrategiak. Zer esanik ez, ondarearen kudeaketan eragina duten zeharkako gaiak ere kontuan hartzekoak dira: aldaketa klimatikoa, pobrezia, giza eskubideak, kultura-aniztasuna, informazioaren eta komunikazioaren teknologiak...

Horrekin guztiarekin adierazi nahi dugu ondarea diziplinen arteko espazio bat dela definizioz eta espazio horretan elkarrekintzan ari diren diziplina askoren (geografia, arte, historia, zientzia, teknika eta abar) kontzeptuak elkarren artean ari direla; beraz, testuinguru interesgarria izan daiteke errealitatea bere batasunean planteatzeko eta ezagutzaren beraren bateratze horren garrantzia ere ezagutzeko.

Ezin dugu ahaztu zeregin horretan espazio-dimentsioen eskalei ere erreparatzen diela arestian esandakoak, garrantzia ematen baitio ondarea tokikotik unibertsalerako norabidean ulertzeari, eta horren bitartez aukera paregabea nahiz beharrezkoa ikasketa helburu gisa izanik gertaera, kontzeptu edo prozedura-edukiak lantzeko (Hernández, 2003).

\subsection{Gizarte-zientziak eta ondarearen didaktika}

Benejam-ek beste zientzia guztiak bezala definitzen du gizarte-zientzien jakintzaarloa (1997): gizakiak iraganean eta orainean gizartean duen jarduna aztertzen da haren bitartez, elkarrekintza edo saihestu ezin den harreman gisa ulertuta.

Hala ere, ez da jakintza-arloaz aurki genezakeen definizio bakarra. Beste definizio bat hartuz, esan genezake gizarte-zientziek arakatzen dituztela gertakari eta egoera geografikoak, historikoak, ekonomikoak, politikoak, soziologikoak, antropologikoak eta kulturalak eta horiek gugan duten eragina; gu geu, beraz, baina gizarteko gizabanako eta parte-hartzaile gisa ulertuta (Benejam eta Pages, 2002; Domínguez, 2004 eta Alonso, 2010). 
1. grafikoa. Gizarte-zientziak eta diziplinak.

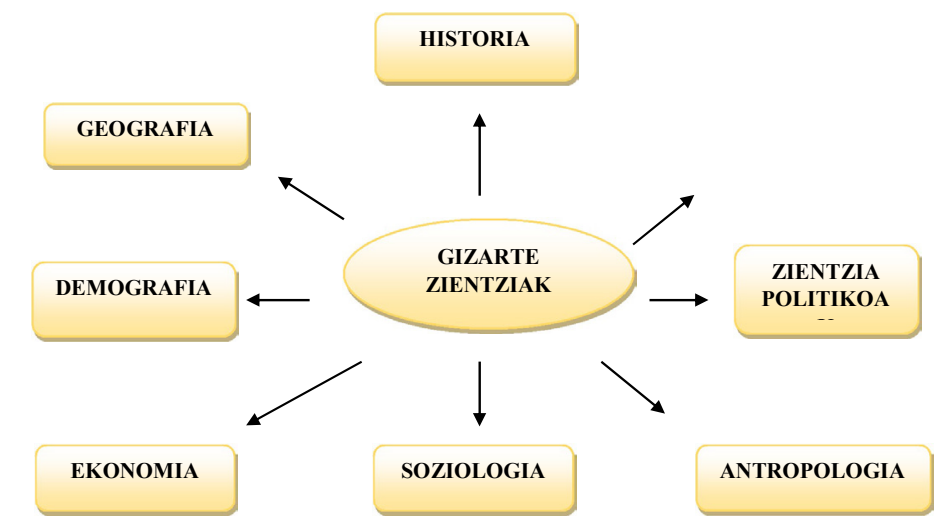

Iturria: Egileak egina, Alonso, 2010: 16tik ateratako datuetatik abiatuz ${ }^{3}$.

Arestian azpimarratutako adituek ere (Benejam eta Pages, 2002; Domínguez, 2004 eta Alonso, 2010) gizarte-zientziak irakatsi eta ikasteko gaur ere gure geletan dauden arazoak adierazten dizkigute, bai Lehen Hezkuntzaz bai Bigarren Hezkuntzaz ari direla. Zertan sumatzen da hori? Esate baterako, ume eta gazteek zailtasunak dituzte zenbait kontzeptu bereganatzeko, hala nola espazio eta denbora historikoa, edo baita gizartearen adierazpenak ulertzeko ere, eta bata zein bestea beharrezkoak dira ondarea bere testuinguruan kokatzeko.

Egoera horri gehitu behar diogu ondareak oso gutxitan izan duela adierazpenik Estatuko curriculumetan eta, zer esanik ez, gizarte-zientzien irakaskuntza praktikoan, artearen historiarekin lotuta ez bada. Normalean, baliabide pasiboa izan da, eta, sarri, testuinguru gabeko bisita batean edota testuliburuetan agertzen diren argazkietan edo ikusitako diapositibetan oinarritua. Hala ere, batez ere 1990eko hamarkadatik aurrera fluxuak aldatu dira, eta gero eta ugariagoak dira proiektuak, ikerketa-taldeak, tesiak eta aipamenak, baita curriculumetan ere, eta, ondareak bere adierazpen holistikoari atxikiz, badirudi aintzat hartzen dela ikaslearen ingurune kulturalaren eta sozialaren eskola-ikerketarako eta, ezagutzaren baliabidetzat harturik, ezagutza sozialaren eraikuntzarako prozeduren ikasketarako (Ramirez de Okariz, 2015b).

Baina, egiari zor, hezkuntza ez-formalarekin alderatuz gero, hezkuntza formaletik hautematen dugun erreakzioa motelagoa (izan) da. Alegia, erakunde eta eragile publikoek batik bat (udalek, museoek, interpretazio-guneek, besteak beste) itzelezko lana egin badute ere hutsune hori betetzeko, hezkuntzari betaurrekoekin begiratuta, hemen egin beharrekoak ugariak dira oraindik; izan ere, bultzatzen dituzten planteamendu pedagogikoak urriak dira, eta erakusketa-toki tradizionalen antzera funtzionatzen dute, hots, diziplina-tratamendua eta jarrera pasiboa nagusitzen dira (Estepa, Wamba eta Jiménez, 2005).

3. Adierazten dugun eskema kontzeptualak irekia izan nahi du; izan ere, gizarte-zientzien jakintzaarloa bizia izanik, definizioak eta beste zientzien ekarpenak ugaritu daitezke.

Bilbo, 2018ko urria-abendua 
Gizarte-zientzien didaktikaren barruan koka daitezke, beraz, ondarearen erabilera eta berari eman beharreko balioari buruzko kezka, hausnarketa eta bultzada, eta, zehatzago esanda, geografiaren eta historiaren didaktikaren barruan eman eta egin beharrekoa. Esaten dugun hori gurean berria bada ere, ez da hainbeste beste lurralde batzuetan. Jar dezagun eredutzat Frantzia. Gérin-Grataloup eta TutiauxGuillon adituek adierazi ziguten zein ziren une hartan geografiaren eta historiaren didaktikaren ikerketaren barruan aintzat hartu beharreko ikerketarako eduki-eremuak (2001). Honatx:

1. Irakaskuntzaren objektua. Gizarte-zientzietan sortzen ari diren informazio eta edukien artean, zein eduki irakatsi behar dira (kontzeptualak, prozedurazkoak eta jarrerazkoak)?

2. Irakaskuntzaren baliabideak. Gelan erabili beharreko zer material eta hizkuntza (ikus-entzunezkoa, hitzezkoa, idatzia...) dira hoberenak edota ez hain erakargarriak irakasteko?

3. Ikasleen produkzioak. Zer aktibitate eta prozedura diseina daiteke ikasketa bermatzeko?

4. Irakaskuntza- eta ikasketa-testuinguruak. Zer testuinguruk bultzatzen dute irakasleak irakastea eta ikasleak ikastea?

5. Ikasketak giza adierazpenak sortzen ditu. Giza adierazpenak errealitate konplexua dira, askotariko jakintzen ezagutzaren eta ikasketaren bidez eraikitzen dena?

6. Diziplinen funtzionaltasuna. Zer esaten digute testu ofizialek (hezkuntzalegeek, curriculum-diseinuek, curriculumek...), testuliburuek, edota inkestek eta behaketek?

7. Formazioa didaktikan. Zer ikertu da? Nolakoa izan beharko luke?

Arestian ikusi dugun bezala, ugariak dira beste diziplina batzuen ekarpenak (historia, geografia, artea, antropologia, politika...) ondarearen tratamenduan. Are gehiago, gizarte-zientzien ekarpenei begira, aukeran, historia eta antropologia izan daitezke ondareari dagokionez ikuspegi zabalen eta integratzaileena duten diziplinak. Izan ere, ondarea elementu baliagarria da gaur egungoa denboran zehar osatu dela ulertzeko; garaian garaiko pertsonek hartutako erabakien ondorioztatze gisa ulertuta, hain zuzen ere (González, 2006).

Pereirok eta Pradok (2008: 22-23) zera diote antropologiari buruz: «Trata de relacionar el objeto, lo material, con su modo de producción, con las vidas vividas, con las "historias" que se encuentran detrás (...). La Antropología propone acercarse al contexto que fue capaz de producirlo». Alegia, ezin izango ditugu ulertu ondarearen adierazpenak ondare hori ekoitzi den testuingurua aintzat hartu gabe eta hura sortzeko eragindako baldintzei arreta jarri gabe.

Baina antropologiak ondareari eskain liezaiokeena harago doa; izan ere, bitartekari ona izan daiteke kultura ulertzeko eta interpretzeko. Alegia, kulturen arteko harremanak errespetuan, komunikazioan eta elkarren arteko ulermenean garatzeko (Pereiro eta Prado, 2008). 


\subsubsection{Gizarte-zientzien eta ondarearen didaktika}

Gizarte-zientzien ikuspegitik, Gonzalezen hitzetan (2006: 39) badirudi identitatearen adierazpen jatorrena dela ondarea eta hartaz jabetuz gizabanakook erraztu genezakeela:

- hiri-identitate arduratsu baten eraketa pertsonala, soziala eta kulturala, inguruaren eta iraganaren kontserbazioan eta errespetuan oinarrituta;

- pentsamendu sozial-kritikoaren garapena, iraganeko lekukoak historikoki kokatzeko eta haiei esanguratasun sozial, politiko eta kulturala emateko;

- inplikazioaren gaitasuna, era arduratsu batez jokatuz tokiko ingurunearen eta ingurune globalaren kontserbazioan, babesean eta dibulgazioan;

- ezagutza historiko eta sozialaren eraketa, denboraren jarraipenaren bidez iragana, oraina eta etorkizuna uztartuz; baina, aldi berean, lehen iturriak erabiliz, kontzientzia historikoaren eta ikerketa historikoaren eraketa.

Ondarearen didaktikaren ikuspegitik, berriz, Espainiako eremuan azken bi hamarkadetatik hona hasi dira ondarea garatzen ikasketa sistematikoaren eremutzat hartuta (eta, nazioartean, ez askoz gehiago), eta, ondorioz, gutxi dira gai horrekin lotutako tesiak eta ikerketa-proiektuak (Prats, 2001).

Beraz, lerro berri bat da ondarearen didaktika. Hala, Frantziako eta Ingalaterrako proposamen didaktikoei jaramon eginez gero, esan genezake ondareari dagokionez ez dutela ikerketa-lerrotzat hartzen gizarte-zientzien didaktikaren barruan. Are gehiago, historiaren didaktikaren ikerketaren testuinguruan barneratuta dakusagu (González, 2006).

Hala ere, bultzatu beharra dagoelakoan gaude; izan ere, arestian esan dugunaren ildoari jarraituz, ondarea baliabide boteretsua izan daiteke, bai gizarte-zientzien didaktikan, baita historiarenean ere, haren bitartez ikasleari azaldu diezaiokegulako oraina iraganean hartutako erabakien ondorioa besterik ez dela, eta gaur egunean ondo aritzea etorkizun hobea eraikitzeko bidea dela.

Esan beharrik ez dago ondarearen didaktika on bat garatu ahal izateko ezinbestekoa dela lehendabizi gaiaz jakitea eta transmisio egokirako prestakuntza pedagogiko eta didaktiko bat izatea; beraz, beharrezkoa da nahitaez de facto irakaslearen formazioa lortzea, hots, irakaskuntza-ikasketa prozesuan interesgarriak diren estrategiak ezagutzea, ikasleek ondarearekin dituzten aurreiritziak eta ustezko motibazioak ezagutzea, eta curriculumak berak eskaintzen duen testuingurua ere aintzat hartzea. Hori da hartu beharreko nahitaezko bidea.

Camillonik (1998) eta Cuencak (2002) esandakoari jarraituz, biek oinarrizko hiru xede adierazten dizkigute gizarte-zientzien irakaskuntzan: ingurune hurbilean nahiz munduko beste lurralde batzuetan bizi diren gizon-emakumeak ulertzea, kulturaaniztasunaren ikuspuntua azpimarratuz; gaitasun kognitiboak ezagutzea, eta gaurko gizarte demokratikoaren barruan bizi izateko balioak partekatzea eta gaitasunak izatea; eta gizabanako gisa oinarrizko beharrizanak garatzea, gizabanakoaren eta gizartearen arteko harremana zainduz. 


\section{Ondarea eta haren eredu didaktikoa diseinatzeko aintzat hartu beharreko irizpideak}

Arestian aipatu dugu ondarea diziplinen arteko espazio bat dela definizioz; geografiako, arteko, historiako, zientziako eta abarretako diziplina eta kontzeptuak elkarrekintzan ari direla, eta, beraz, testuinguru interesgarria izan daiteke errealitatea bere batasunean planteatzeko eta ezagutzen bateratze horren garrantzia ere ezagutzeko. Aldi berean, posible dugu espazio-dimentsioen eskalei ere erreparatzea, tokikotik unibertsalerako norabidea jorratuz eta hala ondarea bere osotasunean ulertuz (Hernández, 2003).

Ondarearen didaktika eragile garrantzitsua izan daiteke gazteei bizitzaren alderdi nabarmenetan laguntzeko, esate baterako: 1) norberarena ez den kulturaren errespetua bultzatzeko; 2) herritar edo hiritar izatearen kontzientzia sortzeko edo areagotzeko; 3) askatasunean eta demokrazian bizitzeko. Horrekin guztiarekin lor genezake kulturen balio historiko, artistiko eta etikoak sustatzea, kulturen arteko errespetua garatzea eta bata zein bestearen bitartez desberdintasunak eta bazterketa saihestea (González, 2006).

Hasi aurretik, ondo legoke didaktika hitza bera azpimarratzea, ondarearen didaktikaz dihardugunean konturatzen baikara adierazpen bat baino gehiago dituela; izan ere, ondarea eduki batekin edo bestearekin lotzeko joera dago: historikoa, artistikoa, kulturala, etnografikoa...

Gizarte-zientzien edo hizkuntzaren didaktikaz dihardugunean, adibidez, ez da halako arazorik izaten; batak zein besteak ondo mugatua dute edukien eremua. Ondarearen didaktikaren kasuan, aldiz, lotuago dago pertsonekin, transmisio horren eragileekin, eta ez hainbeste —nahiz eta oinarrizkoa izan - ondare-elementuekin. Zera esan nahi da, Fontalekin bat eginez (2008: 90-91): «De forma que la didáctica del patrimonio implica, en cierto modo, el aprendizaje de las personas sobre su relación con elementos de diferente naturaleza (histórica, artística, estética...) que potencialmente puede poseer, heredar, legar, transmitir...».

Ondarearen erabilera, baina, ohikoagoa izan da ikertzaileengan irakasleengan baino, eta eskolak puntualki eta bitxikeria gisa erabili ohi du. Horren arrazoia izan da orain arte historiako eta gizarte-zientzietako geletan erabili izan diren metodologiak oso magistralak izan direla, eta ondareak ez du tratamendu espezifikorik izan, eredu tradizionalak erabili izan baitira. Ondarea ez lantzeko arrazoiak lau dira (Bravo, 2002; González, 2006):

1. Irakasle berrien formazio eza: mugatua da, eta ez du eraginik irakaskuntzaikasketa prozesuan; aldi berean, ez dago hausnarketara begira, ezta teoria eta praktika uztartzera begira ere.

2. Curriculum-eredu tradizionalaren eragina.

3. Berrikuntza-esperientzietan parte hartzeko nahiz eragiteko presentzia urria izatea.

4. Irakasleen jarrera dela-eta, garapen urria hezkuntza-zereginaren hausnarketaren, azterketaren eta egokitzapenaren inguruan. 
Estepak (2001) eta Gonzalezek (2006), berriz, beste oztopo batzuk hauteman dituzte:

1. Epistemologikoak edo ondarearen kontzepzioarekin lotuta daudenak. Izan ere, sarri, elementu monumentalekin lotzen da ondarea, eta ez dira balioesten edo ez dira ondaretzat hartzen etnologikoak, teknologikoak, industrialak.... Garrantzia ez ematearen atzean dagoen arrazoia izan liteke ondarearen ikuspegi zabal eta integratzaile bat ez hautematea.

2. Ideologikoak. Aukeratzen den ondarea manipula daiteke. Eta manipulazio mota bi hautematen dira: a) Identitate-diskurtso sinboliko batzuk legitimatzeko egiten den manipulazioa, ikasleengan jarrera kritiko eta erreflexiborik sortzen ez dutenak. Larregi balioesten da norberarena, eta ez dibertsitatea. b) Orain modan dagoen kultura-turismoaren eta aisialdiaren eraginez ondarea errentagarritasun ekonomiko bihurtzeko dagoen joera. Beraz, ondarearen garrantzia erlatiboa da, eta, irizpide zientifikoa baino gehiago, errentagarritasun ekonomikoa sustatzen da.

3. Metodologikoak. Eskolaz kanpoko irteerekin lotuta daude batik bat, eta irakasleari gainkarga dakarkio halakoak antolatzeak, planifikatzeak eta curriculuma egokitzeak.

Lehen Hezkuntzako Ingurunearen Ezagutza jakintza-arloak eta Derrigorrezko Bigarren Hezkuntzako Historiaren (batez ere tokiko historiaren) ekarpenek, baina, beste aurpegi bat adierazten digute: hots, zein garrantzi handia duen ikaslea inguratzen duen testuingurua behatzeak eta arakatzeak. Zertarako?

1. Dakitenaren inguruan hausnartzeko.

2. Beren ezagutzak datozen berriekin berregituratzeko.

3. Beren gizartean (talde, kolektibo, auzo, herri... ) era kritiko eta arduratsuan inplikatzeko eta ekiteko.

Ondarearen irakaskuntza-ikasketarako eredu didaktikoa eraikitzeko prozesu honetan, guk ezinbestean bi ardatzi emango diegu garrantzia. Lehenik, genealogia (jatorria) pedagogiko diziplinarrari, eta, bigarrenik, zer ordenatan emango diegun lehentasuna lau aldagai hauei: irakaslea, ikaslea, testuingurua eta edukia.

\subsection{Genealogia (jatorria)}

Edozein hezkuntza-jarduera hasi aurretik, Zer irakatsi? Zertarako? Zergatik? Nork? Nori?... izaten dira irakasleok planteatu eta erantzun behar izaten ditugun galdegaiak. Horri erantzun zuzenak emateko, diziplina mota askotako eremuak hartzen ditugu aintzat: hezkuntzaren filosofia, psikologia, soziologia eta metodologia.

Ez dago, baina, genealogia bakarra (ez eremu honetan, ezta hezkuntzazientziekin loturiko besteetan ere). Alegia, eredu pedagogiko bakoitzean genealogiaaztarna bati jarrai geniezaioke, eta ereduei koherentzia eta iraunkortasuna eman (Suárez, 2005) ${ }^{4}$.

4. Eredu tradizionala edo edukietan ardaztua; eredu existentzialista edo ikaslearengan ardaztua; konduktista edo tekniketan ardaztua; eraikitzailea edo prozesuetan ardaztua, eta soziala edo testuinguruan ardaztua. 
Gure kasuan, bi alderdiri erreparatuko diegu ondarearen didaktikaren genealogia osatze aldera: alderdi psikologikoa eta alderdi pedagogikoa. Ildo horretan, Dewey, Freire, Gardner, Ausubel, Vigotski eta halako adituen esanekin bat egingo dugu (Ramirez de Okariz, 2015b).

Horiek guztiak baliagarriak izango ditugu ondarearen didaktikaren egitura genealogikoa osatzeko, garbi lagata hezkuntzaren zientziak eta berezko ondarezientziak direla diseinatu nahi dugun didaktika horren oinarria.

Edozein irakaskuntza-ikasketa prozesutan aintzat hartu behar izaten dira aldagai didaktikoak (Lozano, 2005 eta Fontal, 2008); hots, nork irakasten duen (irakaslea), nori irakasten dion (ikaslea), zer irakasten duen (edukia), non eta zenbat irakasten duen (hezkuntza-eremuaren testuingurua). Aldagai horien guztien gainetik badaude beste bi aldagai, zabalagoak biak ere: zertarako irakatsi? (helburuak), eta nora garamatza irakaskuntza-ikasketa prozesuak? (xedea). Eta, aldagai horien guztien ondorioz, metodologiarekin topo egiten dugu; alegia, nola irakatsi-ikasi?

Aldagai horiek guztiak nola antolatu eta lehenesten diren, eredu didaktiko apropos bat diseinatzeko gakoak izango ditugu. Ondarearen didaktikari dagokionez, Fontalek hauek proposatzen dizkigu (2008): edukietan oinarritutako didaktika (objektuak), metodologian oinarritutako didaktika (teknikoa), ikaslearengan oinarritutako didaktika (pertsonala) eta sistema didaktikoan oinarritutako didaktika (ekologikoa).

\subsection{Ondare-elementuak eta irizpideak irakaskuntza-ikasketa prozesuan txertatzea}

Mattozziren (2001) eta Gonzalezen (2006) esanetan, ondarearen didaktikak irakaskuntzarako irizpideak finkatu behar ditu, eta ezagutzaren ikasketaren emaitzak, trebetasunak eta oinarrizko giza mailako gaitasunak ikertu. Bi urte geroago, baina, lau etapatan banatuta, ondarea lantzeko proposamena egin zigun Mattozzik (2003), helburua izanik ikasleari pentsatzen laguntzea historiak eraikitze-prozesu konplexua duela eta deszifratu beharreko ondare-elementu asko dituela. Hona lau etapak:

1. Ezagutza historikoa iturrien bidez eraikitzen dela eta kultura-ondarea hala osatzen dela ulertu.

2. Gertuagoko ondarearen erabileraren funtzioak eta aukerak aurkitu.

3. Hurbileneko ondarearen erabilera esperimentatu.

4. Kultura-ondarea aurkitu.

\subsection{Ondarearen didaktikarako hezkuntza ez-arautuaren irizpideak}

Geletako edo hezkuntza formaleko proposamenez gain badaude beste batzuk eremu edo dimentsio kultural eta sozial zabalera begira, ondarearen garrantzia birbaloratzekoak, eta gaur itzelezko eragina dutenak gure bizitzan, haien helburuetako bat eremu kultural zabal batean ondarea balioestea izanik. Hala ere, Pratsek (2001) eta Gonzalezek (2006) diote lau faktore bete behar direla: 
1. Borondate politikoa egotea ondarea sustatu eta indartzeko. Helburua: gertuko nahiz kanpoko balioespen soziala lortzeaz gain, hezkuntzako erabileran ere orientatuta izatea.

2. Zabalkundea. Irakasleei zuzendutako ikastaroak, irakasleentzako materialak diseinatzea, erakusketak diseinatzea...

3. Museoen planteamendu berri eta modernoak diseinatu eta ezartzea, teknologia berrien erabilera eta elkarrekintza bultzatuz.

4. Bai museogintzan bai eta zabalkundean eta komunikazioan ere interpretazioeta zabalkunde-planteamendu didaktikoak eskaintzea.

Ez dago ukatzerik proposamen horiek (museoa, interpretazio-zentroa, lanmaterialak ...) didaktikan txertatuz gero asko hobetuko litzatekeela ondarearen irakaskuntza-ikasketa prozesua, eta, ildo berean, ezagutza historikoaren ikasketa erraztu eta aberasgarriagoa bihurtuko litzatekeela, esate baterako.

Beraz, ondarea ezagutza sozialaren iturri gisa hauteman behar da: oraina eta lehena, lehenaren eta orainaren uztargile gisa onartu, iraganeko errealitate soziala egunerokoarekin alderatu ahal izateko, eta etorkizunekoa ulertzen hasteko (Suárez, 2005; González, 2006).

\section{Ondorioak}

Krisia orokortu den garai hau ezaugarritzeko orduan, hezkuntza-sistemak berak bizi duen noraezarekin topo egin ohi dugu sarri. Horren erakusle dira bi erakunde eta bi adierazle: familiek sozializazioan bizi duten gabezia eta horren ondorioz eskolak bere gain hartutako funtzioen gainkarga. Bata zein bestea komunitateak berak dauzkan erakunde eta elkarteetako parte dira, eraldatze-prozesuan murgilduak denak ere. Sozializazio-krisi horretan, baina, egoera paradoxikoa bizi dugu; izan ere, krisian dauden erakunde eta elkarteen premia gero eta nabarmenagoa da. Beste era batean esanda, familiaren, eskolaren eta komunitatearen inplikazioak izan beharko luke hezkuntzaren ardatz.

Transmisioak iraganean egindako kultura- (edo ondare-) ibilbidearekin bat egitea dakar, norberaren nahiz kanpokoa den ingurune soziokulturalarekin aritzea; izan ere, azken hamarkadetan, ondareak prestigioa irabazi du erakunde eta herritarren artean. Baina, aldi berean, nahiz eta curriculumean ospe horren isla izan, hezkuntzan ezartzeko arazoak ere badira; besteak beste, corpus pedagogiko eta didaktiko baten jabe ez garelako. Horrek nahitaez dakar hezitzailearen prestakuntzatik abiaraztea, baina ez aparteko bide bat jorratzeko, baizik eta gizarte-zientzietan integratu eta lantzeko. Izan ere, kontrakoa egingo bagenu, ondarearen erabilera isolatua egiteko arriskua legoke. Beraz, onarri teoriko espezifiko bat diseinatu beharrean gaude, ondare-hezkuntza osorik eta haren aldagai guztiak biltzen dituena, nahiz eta onartu badaudela ondarearen errealitate integral gisa hartzeko oztopoak (formazioan, metodologian, baliabideetan...). 
Ondarea ez da diziplina bat, diziplinen arteko espazioa baizik; hots, elkarrekintzan ari diren diziplina askoren testuinguru paregabea. Tokikotik hasita kanpoko errealitateetan hauteman litezkeen ondareak ulertzeko abiapuntua. Hala, ondarearen didaktikaren ikuspegitik, baliabide indartsua izan daiteke, bai gizartezientzien didaktikan, baita historiarenean ere.

Dena den, bai edozein irakaskuntza-ikasketa prozesutan, baita, beraz, ondarearen hezkuntzaren diseinurako ere, ezinbestekoa dugu ohiko aldagaiak ahalik eta ondoen zehaztea, eredu didaktiko apropos bat diseinatzeko. Hasteko, hiruki pedagogikoari arreta jarri behar zaio. Alegia, nork irakasten duen (irakaslea), nork ikasten duen (ikaslea), eta zer irakasten/ikasten duen (edukia). Guztiaren gainetik, baina, badaude beste aldagai zabalago batzuk aintzat hartu beharrekoak: zertarako irakatsi (helburua) eta zergatik irakatsi (xedea). Horiek guztiak aintzat hartuz, nola irakatsi/ikasi (metodoa) aldagaiarekin topo egingo dugu.

Hala eginez gero, ondarearen didaktikarako osagarriak jarriko ditugu, horren bitartez elkarrekiko errespetuan identitatea (pertsonala, soziala eta kulturala) eraikitzeko; pentsamendu soziokritikoa bere testuinguruan interpretatzeko, eta, hala, egungo arazo sozial adierazgarrienak aztertzeko eta alternatibak planteatzeko; tokiko zein eremu zabalagoetako ondarearen kontserbazioan, zainketan eta dibulgazioan inplikatzeko, eta ezagutza nahiz kontzientzia soziohistoriko bat eraikitzeko, horretarako inguruneak eskaintzen dizkigunak erabiliz (González, 2006).

\section{Erreferentzia bibliografikoak}

Alonso, S. (koord.) (2010): Didáctica de las Ciencias Sociales para la Educación Primaria, Pirámide, Madril.

Ávila, R.M ${ }^{a}$ (koord.) (2005): «El patrimonio: una visión integrada en la educación», Investigación en la Escuela, 56, 3-6.

Ávila, R.Mํa eta Mattozzi, I. (2009): La didáctica del patrimonio cultural y la educación de la ciudadanía europea, <http://www.clio92.it/public/documenti/associazione/ Convegniseminari/Relazioneavilamazzotti.pdf> (Kontsulta: 2016/05/30).

Azkarraga, J. (2010): Hezkuntza, gizartea eta eraldaketa kooperatiboa. Zenbait gogoeta, Gizabidea Fundazioaren hausnarketa estrategikorako, LANKI-HUHEZI, Eskoriatza.

Ballart, J. eta Tresserras, J.J. (2001): Gestión del patrimonio cultural, Ariel, Bartzelona.

Benejam, P. (1997): Enseñar y aprender ciencias sociales, geografía e historia en Educación Secundaria, ICE, Bartzelona.

Benejam, P. eta Pages, J. (koord.) (2002): Enseñar y aprender ciencias sociales, geografía e historia en Educación Secundaria, Horsori, Bartzelona.

Bravo, L. (2002): La formación inicial del Profesorado de Secundaria en Didáctica de las Ciencias Sociales en la Universidad Autónoma de Barcelona: un estudio de caso [doktorego-tesia], UAB, Bellaterra.

Camilloni, A.R.W. (1998): «Sobre la programación de la enseñanza de las Ciencias Sociales», in B. Aisenberg eta S. Alderoqui, Didáctica de las Ciencias Sociales II. Teorías con prácticas, Paidós Educador, Buenos Aires, 183-219.

Colom, Antoni J. (1998): «Educación ambiental y la conservación del patrimonio», in J. Sarramona, G. Vázquez eta A.J. Colom (editoreak), Educación no formal, Ariel, Bartzelona, 127-150. 
Cuenca, J.Mª (2002): El patrimonio en las didáctica de las ciencias sociales. Análisis de concepciones, dificultades y obstáculos para su integración en la enseñanza obligatoria [doktorego-tesia], Departamento de Didáctica de las Ciencias y Filosofía, Huelva.

(2003): «Análisis de concepciones sobre la enseñanza del patrimonio en la educación obligatoria», Enseñanza de las Ciencias Sociales. Revista de Investigación, 2, 37-45.

Domínguez, C. (2004): Didáctica de las Ciencias Sociales, Pearson Educación, Madril. Estepa, J. (2001): «El patrimonio en la didáctica de las ciencias sociales: obstáculos y propuestas para su tratamiento en el aula», Iber, 30, 93-104.

Estepa, J.; Wamba A.Mํa eta Jiménez, R. (2005): «Fundamentos para una enseñanza y difusión del patrimonio desde una perspectiva integradora de las ciencias sociales y experimentales», Investigación en la Escuela, 56, 19-26

Fernández Enguita, M. (2001): Educar en tiempos inciertos, Morata, Madril.

Fernández, V. (2005): «Finalidades del patrimonio en la educación», Investigación en la Escuela, 56, 7-18.

Fontal, O. (2003): La educación patrimonial. Teoría y práctica en el aula, el museo e internet, TREA, Gijón.

(2008): «La importancia de la dimensión humana en la didáctica del patrimonio», in Santos M. Mateos (coord.), La comunicación global del patrimonio cultural, TREA, Gijón, 79-109.

Freire, P. (1973): ¿Extensión o comunicación, Siglo XXI, Buenos Aires.

Gerin-Grataloup, A.M. eta Tutiaux-Guillon, N. (2001): «La recherche en didactique de I'histoire et de la géographie depuis 1986, essai d'analyse», Perspectives documentaires en éducation, 53, 5-11.

González, N. (2006): L'ús didàctic i el valore educatiu del patrimoni cultural [doktorego-tesia], Departament de Didàctica de la Llengua i la Literatura de les Ciéncies Socials. Facultat de Ciències de I’Educació, Bartzelona.

Hernández, F.X. (2003): «El patrimonio como recurso en la enseñanza de las ciencias sociales», in E. Ballesteros, C. Fernández, J.A. Molina eta P. Moreno (koord.), El patrimonio y la didáctica de las ciencias sociales, Asociación universitaria de profesores de didáctica de las ciencias sociales, Gaztela-Mantxako Unibertsitatea, Cuenca, 457-459.

Juanola, R.; Calbó, M. eta Vallés, J. (2006): Educació del patrimoni: visions interdisciplinars, Instituto del Patrimonio Cultural de la Universidad de Gerona, Girona.

Llobet, C. eta Valls, C. (2003): «El patrimonio como recurso en la enseñanza de las ciencias sociales en educación primaria», in E. Ballesteros, C. Fernández, J.A. Molina eta P. Moreno (koord.), El patrimonio y la didáctica de las ciencias sociales, Asociación universitaria de profesores de didáctica de las ciencias sociales. Gaztela-Mantxako Unibertsitatea, Cuenca, 467-474.

Lozano, A. (2005): Estilos de aprendizaje y enseñanza, Trillas, Sevilla.

Mateos, S.M. (2008): «Hacia una comunicación global del patrimonio cultural, o cómo potenciar su uso fomentando su preservación», in Santos M. Mateos (koord.), La comunicación global del patrimonio cultural, TREA, Gijón, 19-50.

Mattozzi, I. (2003): «Um bene culturale non fa patrimonio», in D. Ballesteros, C. Fernández, J.A. Molina eta P. Moreno (koord.), El patrimonio y la didáctica de las ciencias sociales, Asociación universitaria de profesores de didáctica de las ciencias sociales. Gaztela-Mantxako Unibertsitatea, Cuenca, 179-196.

Mejías, J. (2008): Estructuras y principios de gestión del patrimonio cultural municipal, TREA, Gijón. 
Nuñez, V. (2003): Los nuevos sentidos de la tarea de enseñar. Más allá de la dicotonomía 'enseñar vs asitir', <http://www.bnm.me.gov.ar/giga1/documentos/EL001422.pdf $>$ (Kontsulta: 2016/09/10).

Pagés, J.; Estepa, J. eta Travé, G. (ed.) (2000): Modelos, contenidos y esperencias en la formación del profesorado de Ciencias Sociales, Publicaciones de la Universidad de Huelva, Huelva.

Pastor, M. (2004): Pedagogía museística. Nuevas perspectivas y tendencias actuales, Ariel, Bartzelona.

Pereiro, X. eta Prado, S. (2008): «Introducción», in X. Pereiro, S. Prado eta H. Takenaka (koord.), Patrimonios culturales: educación e interpretación. Cruzando límites y produciendo alternativas, 12, ANKULEGI Antropologia Elkartea, Donostia,11-37.

Prats, J. (2001): «Valorar el patrimonio histórico desde la educación: factores para una mejor utilización de los bienes patrimoniales», in J. Morales, M.C. Bayod, J. Prats eta D. Buesa, Aspectos didácticos de Ciencias Sociales, 15, ICEZaragozako Unibertsitatea, Zaragoza, 157-169.

Ramirez de Okariz, I. (2014): «Gertuko kultura ondarea eta identitatea», Tantak, 26 (1), 4155.

(2015a): «Lehen Hezkuntzako curriculuma eta kultura-ondarea», UZTARO, 93, 45-67.

(2015b). «Hezkuntza-komunitatearen zeregina kultura ondarearen transmisioan», Tantak, 27 (1), 65-86.

(2017): «Gertuko erakundeak hezkuntza-sisteman parte hartzen: kulturaondarearen transmisioa», UZTARO, 100, 79-110.

Ravé, J.L.; Respaldiza, P.J. eta Fernández, J.J. (1997): «Los Gabinetes Pedagógicos de Bellas Artes y difusión del Patrimonio Histórico de Andalucía», Conciencia Social, 1, 165-171.

Romero, C. (1998): «La ciudad histórica y las estrategias de comunicación», in L. Bartolozzi (koord.), Vivir en las ciudades históricas, Universidad de Extremadura-

Fundación la Caixa, Cáceres. Actas del Seminario de Turismo, Conservación y Rehabilitación del Patrimonio Arquitectónico y Artístico, 13-30.

Suárez, R. (2005): La educación. Teorías educativas. Estrategias de enseñanza-aprendizaje, Trillas, Sevilla.

UNESCO (2011a): «Recomendación que define los Principios Internacionales que deberían aplicarse a las Excavaciones Arqueológicas, 5 de diciembre de 1956», <http:// portal.unesco.org/es/ev.php-URL_ID=13062\&URL_DO=DO_TOPIC\&URL_ SECTION=201.html> (Kontsulta: 2017/05/30).

, (2011b): «Recomendación sobre la protección de los bienes culturales muebles», <http://unesdoc.unesco.org/images/0011/001140/114032s.pdf\#page=183> (Kontsulta: 2017/05/30).

, (2011c): «Recomendación sobre la Protección en el Ambito Nacional del Patrimonio Cultural y Natural», <http://unesdoc.unesco.org/images/0011/001140/114044s. pdf\#page $=150>$ (Kontsulta: 2017/05/30).

Valenzuela, T. eta Viloria, N. (2008): «Estrategias metodológicas para la enseñanza del patrimonio local en el área de educación para el trabajo: Unidad educativa "Juan Bautista Dalla Costa" del municipio de Boconó del Estado Trujillo», Investigación y Postgrado, 23. bol., 3, 251-276. 
